\title{
LONG TERM PRESERVATION OF CADAVERS: SUBSTITUTION OF FORMALIN WITH PHENOXYETHANOL: NEED OF THE HOUR
}

\section{Neeta Chhabra.}

Associate professor, Department of Anatomy, GS Medical College and Hospital, NH-24, Near Railway Station, Pilkhuwa, Hapur, India.

\section{ABSTRACT}

Introduction: Formaldehyde is not just a human carcinogen but the cause of many other unwanted hazards; respiratory distress, red eyes, etc. Occupational health authorities throughout the world are therefore likely to increase the strictness of regulations for the use of formaldehyde within anatomical disciplines.

Aim: This study evaluates the effectiveness of Phenoxetol (Phenoxyethanol) as suitable alternative to formaldehyde for long term preservation of cadavers.

Results: The soft consistency, colour and flexibility, of cadavers preserved in Phenoxetol, was found to be suitable for dissection \& demonstration purposes.

Conclusion:Phenoxetol proves to be a viable replacement of formaldehyde.Its efficacy as a preservative and fixative is supposed to be better than formalin. In addition to avoiding the well-known hazardous effects of formaldehyde, the use of Phenoxetol also prevents the pungent and irritating smell associated with formalin and other local and systemic manifestations of its toxicity.

KEY WORDS: Formaldehyde, Phenoxetol,Preservation, Cadavers.

Corresponding Author: Dr Neeta Chhabra, Associate Professor, Department of Anatomy, GS Medical College and Hospital, Nh-24, Near Railway Station, Pilkhuwa, Hapur -245304, India.

Mobile: 9811113296E-Mail: neetachhabra86@gmail.com

Access this Article online

Quick Response code

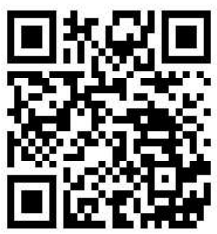

DOI: $10.16965 /$ ijar.2020.158
Journal Information

International Journal of Anatomy and Research

RG Journal ISSN (E) 2321-4287 | ISSN (P) 2321-8967

Impact: 0.21* https://www.ijmhr.org/ijar.htm

DOI-Prefix: https://dx.doi.org/10.16965/ijar

\section{Article Information}

Received: 27 Apr 2020

Peer Review: 27 Apr 2020

Revised: None
Accepted: 15 May 2020

Published (O): 05 Jun 2020

Published (P): 05 Jun 2020

\section{INTRODUCTION}

Cadaveric dissection has been the paradigm of anatomy teaching since the Renaissance, and defining experience of medical teaching since the 16 th and 17 th centuries $[1,2]$. The practice of cadaveric dissection helps students to grasp the three dimensional anatomy and concept of innumerable variations. Dissection has also been called "sharp end" of medical education as through dissection, students are able to get the feel of the human tissues and structures of the human body $[3,4]$. Cadaver and museum specimens help the medical students to learn regional and topographic anatomy structure including vessels, nerves and muscles of human body[5]. A comparison of educational tools revealed that human bodies have distinct properties and that there are no viable alternatives[6].

For the use of human bodies in dissection rooms, the appropriate preservation of the cadaver is the most important prerequisite i.e. the cadaver should be safe from harm, destruction or decomposition. This is achieved by treating the cadaver with special chemicals, and the procedure is called Embalming. Embalming leads to a long-term preservation of structure with minimal shrinkage and distortion of tissue and 
also prevents over-hardening. The most common chemical used for this purpose is Formaldehyde which has been used as a fixative in anatomy, pathology, and in embalming since the 20th century [7]. But Formaldehyde has been shown to cause mutation in various primitive organisms $[8,9]$ and in cultured mammalian cells $[10,11]$. Furthermore, inhaled formaldehyde caused nasal carcinoma in rats and mice and subcutaneously injected formaldehyde caused sarcoma in rats $[12,13]$. Recent epidemiologic surveys among embalmers and industrial workers exposed to formaldehyde may indicate an increased cancer risk even to humans [14].

Formalin has an odour that many students and faculty members find unpleasant. Chemical hypersensitivity has been attributed to exposure to formaldehyde or other volatile compounds. Students develop many troublesome symptoms like nausea, headache, and gastrointestinal disturbance during cadaver dissection or complain of disorders due to irritation of the mucous membrane of the eye and nose [15].

The anatomists, technicians, and students in the laboratories are continually exposed to Formaldehyde during their dissection course. The level of exposure depends on the duration of time spent in the dissection hall and the working environment [16].

In developed countries, The Occupational Safety Health Administration (OSHA), formaldehyde standard and equivalent regulations in states protect workers exposed to FA and apply to all occupational exposures to FA. The permissible exposure limit (PEL) for FA in the workplace is $0.75 \mathrm{ppm}$ of air measured as an 8-hour time-weighted average. The standard includes a second PEL in the form of a short-term exposure limit of $2 \mathrm{ppm}$ which is the maximum exposure allowed during a 15-minute period [17]. At concentration above these permissible limits, protective measures should be employed like giving respirators, putting administrative controls, exposure monitoring and other required procedures. Very few literature has been published on indoor FA concentrations in Medical Colleges of India. Reports from other countries have reported FA levels above prescribed standards that could be harmful to those exposed.Several western countries have restricted the use of formalin. But in India there are no standards for air monitoring of formaldehyde levels in dissection hall and also there are no rules governing the use of formalin and of its inclusion in occupational health hazards. Moreover FA level monitoring, cadaver positioning and ventilation strategies are also not rigorously inspected by any medical regulatory bodies across the world including India.

Some laboratories have already found ways of abandoning the use of formaldehyde and phenol for long-term preservation of specimens for dissection and museum purposes. Most widely used among such methods is the immersion of previously formaldehyde and phenol-fixed specimens in alcohol solutions ranging in concentration up to $75 \%$ [18]. This principle was reinvestigated by Bjorkman and Christensen in 1982 who found the atmospheric formaldehyde concentration was lowered to below $0.5 \mathrm{ppm}$ when the specimens had been extracted for about 3 months in $20-50 \%$ ethanol. However, ethanol in high concentrations is expensive, flammable, and evaporates rapidly.In addition, most tissues were subjected to excessive hardening and loss of natural colours in these concentrations. In lower concentrations the antimicrobial action of ethanol may be unsatisfactory [19].

Another method described by Owen and Steedman $(1956,1958)$ was use of phenoxetol [20]. They found various zoological specimens, previously fixed by any desirable method, to be well preserved for years in a solution of $1 \%$ propylene phenoxetol (1-phenoxy-propan2-01) alone or in combination with $0.2 \%$ "Nipa" esters ("Nipastat" or mixture of alkyl esters of 4-hydroxybenzoic acid). This technique was recommended for general use by Spence 1967, and Steinmann et al in 1975reported good results on veterinary medical and zoological specimens. But was not reported to be used on human material $[18,21]$. Frolich et al carried out a study in 1984 with phenoxetol as long term preservative where they found that the material had remained soft and flexible with a consistency and colour retention suitable for dissection and demonstration purposes for upto 10 years. Fungal attacks were rare and no bacteria could be grown from such specimens. 
Microscopical structure of most tissues also remained satisfactory after 5years in 1\% phenoxyethanol [22].

Tandon et al in a study carried out in 2014 found phenoxetol to be a viable replacement of Formaldehyde for long term preservation of cadavers. Moreover it was observed that students found experience with cadavers preserved in phenoxetol very pleasant as it has a fruity smell as compared to the offensive odour of formaldehyde $[23,24]$.

In view of above an attempt was made to improve the environment of our dissection hall by substituting formaldehyde with phenoxyethanol (ethylene glycol mono phenyl ether) or phenoxetol, a non-toxic chemical for long term preservation of embalmed cadavers.

\section{MATERIALS AND METHODS}

The present study was conducted at GS Medical College \& Hospital Pilkhuwa, Hapur. 10 cadavers ( 7 males \& 3 females) between 56 to 87 years of age were taken for the study. All the cadavers were those who had opted to voluntarily donate their bodies before death for medical research purpose. These cadavers had been embalmed 4-6 months earlier by singlepoint embalming. The embalming fluid as per below composition was injected in the common carotid or femoral artery using embalming perfusion pump.

Composition of Embalming fluid:

$\begin{array}{lc}\text { Formalin: } & 2000 \mathrm{ml} \\ \text { Methanol: } & 1000 \mathrm{ml} \\ \text { Glycerine: } & 500 \mathrm{ml} \\ \text { Phenol: } & 500 \mathrm{ml} \\ \text { Sodium citrate: } & 15 \mathrm{gm} \\ \text { Sodium borate: } & 15 \mathrm{gm}\end{array}$

Thymol: $\quad$ Few crystals

Water: $\quad$ To make it to $8000-1000 \mathrm{ml}$

After the initial vascular injection the cadavers were observed for 24-48 hrs and supplementary injections of the same fluid was given locally wherever the initial injection proved unsatisfactory. The cadavers were then transferred to tanks filled with $4 \%$ formaldehyde and stored there for a period ranging between 4 to 6 months. After this period the cadavers were taken out and washed thoroughly with tap water and kept on dissection hall tables for $24 \mathrm{hrs}$ to remove the fixative by evaporation. They were then transferred to a tank filled with $1 \%$ Phenoxetol in water. The capacity of our tank is 1400 litres and taking water displacement by cadavers into consideration, the tank was filled only with 900 litres of tap water and nine litres of phenoxyethanol was poured into it thereby making $1 \%$ solution. The cadavers were left in this solution for a period of at least 3-4 months before they were used for the purpose of dissection. The solution was prepared in the month of May and cadavers were taken out for dissection in September. During this period the tanks were regularly observed for any discoloration of fluid and signs of fungal infection. During the dissection schedule the bodies remained on stainless steel tables for the week, covered with sheets soaked in $1 \%$ Phenoxetol. During weekends the bodies were re-immersed in the tanks having $1 \%$ Phenoxetol. Phenoxetol in the tanks was renewed once in the month of December, when the solution was discoloured by exudate from the cadavers and again after 3 months in the month of March. The bodies were thus treated by a minimum of two successive baths of $1 \%$ Phenoxetol to remove most of the remaining free aldehydes left by the fixative solutions. Dissected specimens were also stored in $1 \%$ Phenoxetol and were used for demonstration purposes.

\section{RESULTS}

In the present study we found that the cadavers and dissected specimens preserved in $1 \%$ phenoxetol were good for dissection purposes. The unpleasant and intrusive smell of formaldehyde and phenol traditionally found in dissection rooms was markedly reduced. Much of the rigidity of the tissues caused by the initial aldehyde fixation disappeared after some weeks in Phenoxetol and all tissues gain a flexible, partly elastic, consistency not unlike the consistency of fresh unfixed tissue, and well suited for dissection and demonstration purposes, especially for demonstration of movements across joints. The colour retention of tissues was good and the tissue remains aesthetic even after longer use as prosections. There was no sign of microbial or fungal infection in cadavers. We are of the opinion that $1 \%$ 
Phenoxetol enhances life like tissue colours rather than disturbing them. As far as cost of the solution is considered only one can of 25 litres of Phenoxetol with an approximate cost of Rs 13,000 was sufficient for whole year whereas the expenditure on formaldehyde is around Rs 5,000. Thus cost factor of phenoxetol is not a big issue taking into consideration its low toxicity compared to formaldehyde.

\section{DISCUSSION}

Formalin has been the most widely accepted chemical for preservation of cadavers for dissection purposes, as it is economically an excellent preservative and fixative solution. The benefits of using formalin, its cost effectiveness, and its proper fixation and efficient preservation of tissue, have to outweigh its adverse effects on the health of those working with it.Moreover formalin has been recently classified as carcinogen which is even suspected of causing adverse reproductive and developmental effects[25]. To limit the exposure of formalin various methods are being followed like ventilated dissection halls, use of exhaust fans and use of gloves during dissections, still the observed FA levels in dissection halls are found beyond the prescribed guidelines laid down by regulatory bodies. This is considered to be harmful for students and teachers health[26]. Since formalin is toxic, an alternative and a safer fixative detection is important. Phenoxyethanol, discovered by Frolic et al in 1984 has been found to be an excellent alternative to formalin. It is already being used for long term preservation of cadavers by few medical colleges with good results [22].

Phenoxyethanol is a glycol ether with known bactericidal and antifungal properties with an oily colourless appearance and a characteristic pleasant odour [27]. It is a widely used preservative to prevent bacterial and fungal contamination, especially in cosmetic industry and for pharmaceutical products. It was tried early in local treatment of burns and wounds, especially against Pseudomonas aeruginosa or Pyocyanea infections, because it proved to show little skin or tissue irritation on local application as a solution or ointment. It has shown low toxicity when injected subcutaneously, intra-peritoneal or intravenously in various laboratory animals [28]. Phenoxetol is chemically related to propylene phenoxyethanol, which was used, by Owen and Steedman in 1958 as a preservative for zoological specimens. Both substances have much the same antibacterial activity. Propylene phenoxyethanol though more effective against moulds and yeast, should ideally be preferred for preservation purposes. Since phenoxetol gives fully satisfactory results as a preservative and is cheaper than propylene phenoxyethanol, phenoxetol is commonly used [20]. In a study carried out by Burke and Sheffner in 1976 it was proved that phenoxetol as preservative gives satisfactory results from a microbiological point of view and also for long-term storage of human bodies for dissection purposes when compared with more conventional preservative techniques [29].

Though Phenoxetol is combustible, it must be preheated before ignition can occur (NPFA Fire Rating 1) and a harmful contamination of the air will not or only very slowly be reached on evaporation of this substance at room temperature. Concerning potential health risks, its use has been attributed to irritation, sensitization, and allergic contact dermatitis at low incidence rates in large cohort studies [30,31].

The most important advantage of Phenoxetol preservation still seems to be its low toxicity, as mentioned above. Skin contact which should be avoided using the phenyl-mercury compound seems to present no problem with phenoxetol [32]. On the contrary, Phenoxetol is recommended as an antiseptic ingredient in medical creams and ointments [24].

Despite its widespread use for many years, contact allergy to Phenoxetol has been very rarely described [7]. Erythema and scaling that occurred on intradermal injection of phenoxetol in rabbits were not associated with gross or histopathologic changes and were not considered toxicologically significant [32]. Few case reports exist on PE causing pain, headache, tremor, and central nervous system depression when swallowed intentionally or inhaled in large quantities. Consequently, standard safety precautions must be followed including room ventilation, protective gloves, clothing and safety goggles when handling Phenoxetol [33]. 
The results of this study are in agreement with those reported by Owen and Steedman in 1958 on zoological samples and by Steinmann et al in 1975 on veterinary and zoological samples $[20,21]$. Three other studies on human cadavers by Frølich et al, Tandon et al and Wineski and English highlight the potential of PE in lowering the exposure to formaldehyde and phenol. They described that soft tissue pliability can be recovered by partly removing the formaldehyde and phenol from their fixatives $[22,23,34]$. Their findings are in large agreement with the results presented here, where increasing pliability is found when tissues are exposed to the PE-based conservation fluid.

From an anatomical point of view, Phenoxetol gives superior results to those of most other preservatives. Sehdev et al in 1963 proved that the colour retention of tissues preserved in phenoxyethanol was good and the tissue consistency softer and more flexible than that achieved by ethanol preservation [35]. Thiel in 1992 and Eisma et al in 2013 observed that since no mineral salts are used in the preservative fluid, other embalming methods using such salts will definitely be superior in terms of colour retention $[36,37]$. Smell and mucosal irritation may be suspected at formaldehyde concentrations as low as $0.15 \mathrm{ppm}$ (38). In a study carried out by Tandon et al on medical students phenoxyethanol caused little skin irritation as compared to formaldehyde and phenol. They reported few cases of mucosal irritation or smell with phenoxyethanol which may be due to the formalin used during embalming of cadavers [23].

A second aspect of PE preservation is the onset of bacterial or fungal growth. Though its onset only occurs under extreme storage conditions, for example, direct sun exposure of storage cabinets with condensing water washing out chemicals or contaminations introduced by normal skin commensal micro-organisms of the users or air-borne fungi. These can be successfully taken care of by improvements in storage temperature, thorough cleaning with Trigene and $\mathrm{PE} /$ Arquad-75, to treat and prevent contamination [33].

Earlier studies by Frolich et al had stressed that Phenoxetol or propylene phenoxyethanol cannot be used for initial fixation purposes as it has no ability to arrest autolysis, and unless other proper fixatives are used, the tissues will decompose rapidly [22]. But recently published Phenoxyethanol-based embalming ("Crosado" technique) has shown to give reliable and reproducible results for the anatomical fixation over the period of nearly two decades of use at the University of Otago. They have proved that phenoxyethanol based technique is suitable for embalming human tissues for a variety of dissection-based courses and prosections, providing a suitable basis for plastination and histology. A major advantage of the technique is its potential to reduce the amount of formaldehyde to a minimal content, while at the same time being robust enough to be performed outside of the anatomy setting. The specimens resulting from $\mathrm{PE}$-based fixation were durable when used in the dissection course and provided a level of pliability to position the cadaver for dissection. There was no unpleasant or intrusive smell as formaldehyde based or Thiel embalming may cause, and the tissues remain aesthetic even after longer use as prosections. In fact the PE-based fixation complements existing embalming techniques and provides an alternative to the use of hazardous chemicals or minimizes its application (33). Brenner in 2014 documented that with phenoxyethanol the muscles remain pliable and joints freely mobile compared to formalin which causes extreme rigidity [7].

Our objective to replace formaldehyde as long term preservative with a less toxic alternative was thus achieved. It must be stressed however that any of such alternatives will have its adverse effects too. Some animal experiments have shown that oral or parenteral administration of 0.5 to $2 \%$ phenoxetol can cause haemolysis in rabbits and liver and reproductive toxicity in Swiss CD-1 mice [32,39].

However, phenoxetol being a high boiling liquid with a low vapor pressure, exposure to vapours to a concentration sufficient to cause such effects is unlikely at room temperature [40]. A case of an immediate hypersensitivity reaction has been reported by Bohn and Bircher in 2001[41].

Limitations of the use of phenoxetol seem to be 
requirement of large amount of chemical and its prohibitory pricing. In a very recent review article by Brenner et al, Phenoxetol has been described as relatively inexpensive, non-flammable, slow to evaporate, effectively antimicrobial and an excellent tissue preservative and softener [7]. Our studies are in agreement with Brenner et al as use of phenoxetol only slightly increased the overall expenditure on preservative. Thus by replacing Formalin with phenoxetol, our efforts to improve the working conditions in the dissection hall will benefit the students, teachers and the staff in charge of the embalming procedure itself. The prolonged exposure of the latter group to formaldehyde fumes in the embalming room seems equally important to consider. We believe that a reduced exposure of this group to formaldehyde vapours must be sought via the reduction or replacement of formaldehyde as primary fixative and improved ventilation at critical places within the embalming room. Towards addressing this issue the Thiel method of embalming or its modification (Eisma et al, 2013) or Crosado technique can be tried and evaluated subsequently.

\section{CONCLUSION}

The acute toxic effects of formalin are well known in medical fraternity. But the occupational hazard due to FA is not given utmost consideration despite of necessity due to lack of regulations either from governing authorities or regulatory bodies. An excellent alternative to formalin is phenoxyethanol. In our experience Pheno-xetol proves to be a viable replacement of formaldehyde. Its efficacy as a preservative and fixative is supposed to be better than formalin. In addition to avoiding the well-known hazardous effects of formaldehyde, the use of Phenoxetol also prevents the pungent and irritating smell associated with formalin and other local and systemic manifestations of its toxicity. It is simple to use and adds only a small contribution to the overall cost of preservative. At present initial fixation of cadavers is being done with Formalin. It is recommended that initial fixation may also be slowly replaced and done with phenoxetol. Thus with proper guidance and effort we may be able to give students an odour free and harmless environment in the dissection hall.

\section{Conflicts of Interests: None}

\section{REFERENCES}

[1]. Richardson R. Death, dissection and the destitute. London and New York:Routledge and Kegan Paul; 1987.

[2]. Persaud TVN. Early history of human anatomy: from antiquity to the beginningof themodern area. Springfield, Illinois:CCThomas.1984.

[3]. Winkelmann A. Anatomical dissection as a teaching method in medical school: areview of the evidence. Med Edu 2007;41:15-22.

[4]. Maguire P. Barriers to psychological care of the dying. Br Med J (Clin Res Ed)1985;291:1711-13.

[5]. Coleman R, Kogan I. An improved low-formaldehyde embalming fluid to preservecadavers for anatomy teaching. J Anat 1998;192(3):443-6.

[6]. Brenner E, Maurer H, Moriggl B, et al. The human cadaver as an educationaltool: classification and comparison with other educational tools. Ann Anat2003;185:229-30.

[7]. Brenner E. Human body preservation: old and new techniques. J Anat 2014;224:316-44.

[8]. Nishioka H. Lethal and mutagenic action of formaldehyde in $\mathrm{HCR}^{+}$and HCRstrains ofEscherichia coli. Mutat Res 1973;17:261-5.

[9]. Slizynska H. Cytological analysis of formaldehyde induced chromosomal changesin Drosophila melanogaster. Proc R Soc Edinb1957;66:288-304.

[10]. Ragan DI, Boreiko CJ. Initiation of $\mathrm{C} 3 \mathrm{H} / 10 \mathrm{~T} 1 / 2$ cell transformation by formalde-hyde. Cancer Lett1981;13:325-31.

[11]. Ross WE, Shipley N. Relationship between DNA damage and survival in formal-dehyde treated mouse cells. Mutat Res1980;79:277-83.

[12]. Albert RE, Sellakumar AR, Laskin S, Kuschner M, Nelson N, Snyder CA. Gaseousformaldehyde and hydrogen chloride induction of nasal cancer in the rat. J NatlCancer Inst 1982;68:597-603.

[13]. Watanabe F, Matsunaga T, Soejima T, Iwata Y. Study on aldehyde carcinogenicityin experimentally produced rat sarcomas by repeated injections of aqueoussolution of formaldehyde. Japan J Cancer Res 1954;45:451-52.

[14]. Hauptmann M, Lubin JH, Stewart PA, Hayes RB, Blair A. Mortality fromlymphohematopoietic malignancies among workers in formaldehyde industries.J Natl Cancer Inst 2003;95:1615-23.

[15]. Shiksha J, Ranjana A, Kamaljit B, Neeraj K. Preventive measures and suggestedguidelines to reduce the chemical health hazards on medical students andeducators. Res J Pharmacology \& P Dynamics 2015;7(3):147-50.

[16]. Raja DS, Sultana B. Potential health hazards for students exposed to formaldehyde in the gross anatomy laboratory. J Environ Health 2012;74:36-40.

[17]. SHA fact sheet [Internet]. Washington, DC: Occupational Safetyand HealthAdministration; 2019 [cited 2019 Oct 20]. Available from: https:// www.osha.gov/Osh Doc/data_General_Facts/formaldehyde- factsheet.pdf. 
[18]. Spence TF, Zuckerman S. Teaching and display techniques in anatomy andzoology. Pergamon Press Oxford.1967.

[19]. Bjorkman N, Christensen KM. Extraction of dilute ethanol of formaldehyde-fixeddissecting specimens. an efficient method to reduce health hazards. Acta Anat1982;112:1-8.

[20]. Owen G, Steedman H. Preservation of molluscs. J Molluscs Stud 1958;33:101-3.

[21]. Steinmann W, Ebeling R, Goepel U. The preservation of medical and zoologicalpreparations in Phenoxetol. Der Praparator (Bochum)1975;21:8-11.

[22]. Frolich KW, Endresen LM, Knutsen A, et al. Phenoxyethanol as a non-toxicsubstitute for formaldehyde in long term preservation of human anatomicalspecimens for dissection and demonstration purposes. Anat Rec 1984;208(2):271-8.

[23]. Tandon A, Bhatnagar R, Pokhrel R, Solanke K. Phenoxetol as a formaldehyderemoving agent for long-term preservation: Our experience. Eur J Anat 2014;18(4):267-72.

[24]. Stecher PG. In: The Merck Index: an encyclopedia of chemicals and drugs.Merckand Co, Rahway, NJ.1968.

[25]. Latika Arora. Exposure of medical fraternity to formaldehyde in Anatomy andsearch for better alternatives to Formalin. J D and Med Sci 2014;13(10):567.

[26]. Gahukar S, Ramteke U, Majumdar D, Malviya R, Patil D, Trivedi J, Rao C, KaleAH. Prevalence of formaldehyde in indoor air of gross anatomy laboratory andcadaver storage room of a medical college. J Environ Occup Sci 2014;3:181-5.

[27]. Lowe I, Southern J. The antimicrobial activity of phenoxyethanol in vaccines. LettApp IMicrobiol2014;18:115-16.

[28]. Gough J, Berry H, Still B. Phenoxetol in the treatment of pyocyanea infections.The Lancet, 1944;244:176-8.

[29]. Burke PA, Sheffner Al. The antimicrobial activity of embalming chemicals andtopical disinfectants on the microbial flora of human remains. Health Lab Sci1976;13:267-70.

[30]. Cheng S, Leow YH, Goh CL, Goon A. Contact sensitivity to preservatives inSingapore: frequency of sensitization to 11 common preservatives 20062011.Dermatitis 2014;25:77-82.
[31]. Horev L, Isaksson M, Engfeldt M, Persson L, Ingber A, Bruze M. Preservativesin cosmetics in the Israeli market conform well to the EU legislation. J Eur AcadDermatol Venereol2015;29:761-66.

[32]. Breslin WJ, Phillips JE, Lomax LG, Bartels MJ, Dittenber DA, Calhoun LI, MillerRR. Hemolytic activity of ethylene glycol phenyl ether (EGPE) in rabbits. FundamApplToxicol1991;17:466-81.

[33]. Crosado B, Loffner S, Ondruschka B, Zhang M, Zwirner J, Hammer N. Phenoxyethanol-based embalming for anatomy teaching: an 18 years' experience withCrosado embalming at the university of Otago in New Zealand. Anat Sci Educ2020;0:1-16.

[34]. Wineski LE, English AW. Phenoxyethanol as a nontoxic preservative in thedissection laboratory. Acta Anat1989;136:155-8.

[35]. Sehdev H, Mcbride J, Fagerlund U. 2-Phenoxyethanol as a general anaestheticfor sock eye salmon. J Fish Res Bd Canada 1963;20:1435-40.

[36]. Thiel W. The preservation of the whole corpse with natural color [Article in German:Die KonservierungganzerLeichen in naturlichenFarben]. Ann Anat1992;174:185-95.

[37]. Eisma R, Lamb C, Soames RW. From formalin to Thiel embalming whatchanges ? one anatomy department experiences. Clin Anat 2013;26(5):564-71.

[38]. Bourne HG, Seferian S. Formaldehyde in wrinkle proof apparel processes-tearsfor milady. Ind Med Surg1959;28:232-3.

[39]. Heindel JJ, Gulati DK, Russell VS, Reel JR, Lawton AD, Lamb IV JC. Assessmentof ethylene glycol monobutyl and monophenyl ether reproductive toxicity using acontinuous breeding protocol in Swiss CD-1 mice. FundamApplToxicol1990;15:683-96.

[40]. SIDS Initial Assessment Report Ethylene Glycol Phenyl Ether (2005) Accessedon 06 Jan 2020. Available at: http://www.chem.unep.ch/irptc/sids/OECDSSIDS /122996.pdf

[41]. Bohn S, Bircher AJ. Phenoxyethanol induced urticaria. Allergy 2001;56:922-3.

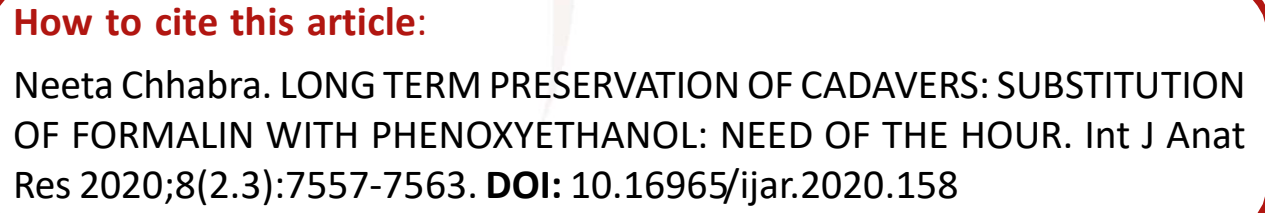

